\title{
Evaluation of groundwater quality in and around Nagercoil town, Tamilnadu, India: an integrated geochemical and GIS approach
}

\author{
Y. Srinivas • D. Hudson Oliver • A. Stanley Raj • \\ N. Chandrasekar
}

Received: 10 January 2013/Accepted: 27 May 2013/Published online: 14 June 2013

(c) The Author(s) 2013. This article is published with open access at Springerlink.com

\begin{abstract}
This study was made to find the ground water quality for samples of the town located in the southern most end of India. The study was carried out to evaluate the major ion chemistry, the factors controlling water composition, and suitability of water for both drinking and irrigation purposes. Totally, 21 ground water samples were collected randomly from bore wells and hand pumps throughout the Nagercoil town and its surroundings. The collected samples were analyzed for major ions and the analytical data were interpreted according to published guide lines. The spatial maps show that the concentration of the chemical constituent in ground water varies spatially and temporarily. Sodium is the most dominant cation with $\mathrm{Cl}^{-}$and $\mathrm{HCO}_{3}{ }^{-}$as the dominant anion. The abundant of the major is as follows: $\mathrm{Na}^{+}>\mathrm{Cl}^{-}>\mathrm{Mg}^{2+}>\mathrm{K}^{+}$which is equal to $\mathrm{HCO}_{3}{ }^{-}>\mathrm{Cl}^{-}>\mathrm{SO}_{4}$. Only one-third of the samples best fit for both consumption and agricultural purposes. The spatial maps show high contamination along the southern region of the study area. Total hardness of the collected samples lies between 60 and $490 \mathrm{mg} / \mathrm{l}$ reveals that the $33 \%$ groundwater samples exceeds the safe limit of $300 \mathrm{mg} / \mathrm{l}$. Total dissolved solids (TDS) in the study area ranges between 67 and 2,086 $\mathrm{mg} / \mathrm{l}$ with a mean value of $523 \mathrm{mg} / \mathrm{l}$. High total hardness and TDS in few places identified that the ground water is unsuitable for drinking and irrigation. In these places, the aquifers are subject to contamination from sewage effluents and excess use of fertilizer and pesticides in agriculture. Such areas require adequate drainage and introduction of alternative salt tolerance cropping.
\end{abstract}

Y. Srinivas · D. H. Oliver $(\bowtie) \cdot$ A. S. Raj · N. Chandrasekar Centre for GeoTechnology, Manonmaniam Sundaranar University, Tirunelveli 627012, Tamil Nadu, India e-mail: hudson2612@gmail.com
Keywords Ground water - Drinking and irrigation water quality - Spatial distribution - Water quality index . Nagercoil $\cdot$ India

\section{Introduction}

Water is an essential input not only for the human existence, but also for all developments. Demand for ground water has increased tremendously in recent years due to the industrialization, urbanization, population increase, and intense agricultural activities. Many cities and towns in India obtain ground water through municipality network and extremely from private bore wells. Hence, knowledge of hydrochemistry is important to assess the ground water quality in any area in which the ground water is used for both irrigation and drinking needs. The water quality assessment may give clear information about the sub surface geologic environments in which the water presents (Raju et al. 2011). Over exploitation of ground water has immensely affected its quality and quantity. In several parts of the world, lots of studies have been already carried out to assess the geochemistry of ground water (Samira and Jurdi 2007; Siddiqui et al. 2005; Belkhiri and Mouni 2012). In India, several studies were carried out on the groundwater and its quality. Jain (1996) carried a research on the hydrogeochemistry and groundwater quality of Singhari river basin, district of Chattarpur which belongs to Madhya Pradesh State. Kaushik et al. (2000) studies the groundwater quality of Ambala and Nilokheri Cities in Haryana. Sarath Prasanth et al. (2012) evaluate the groundwater quality and its suitability for drinking and agricultural use in the coastal stretch of Alappuzha district in Kerala. In Tamilnadu, several researchers such as Ramesh et al. (1995), Sreedevi 
(2002), Rajmohan and Elango (2005), Srinivasamoorthy et al. (2011), Sajil Kumar and James (2013), and Krishna Kumar et al. (2011) carried some works in the groundwater quality studies. Therefore, an evaluation of quality of the groundwater is an important task to be done in a scientific way. To provide a simple and valuable tool for decision making on the groundwater quality, an integrated approach of both, water quality index (WQI), and geographical information system (GIS) can be used.

WQI is a mathematical tool which can transform large amount of water quality data into a single number which represents the water quality level. Several researchers have already used the WQI as a tool to obtain the quality of groundwater (Tiwari and Mishra 1985; Debels et al. 2005; Sandow and Adadow. 2010; Vasanthavigar et al. 2010). The spatial distribution of various hydrochemical parameters can be successfully mapped using GIS. It is already used by numerous authors to obtain good results (Ahn and Chon 1999; Nas and Berktay 2010; Dar et al. 2011). Some previous works were done concentrating the coastal area near the southern side of the study area. In the earlier years, the groundwater quality in the study area was better when compared to recent years (Bhagavathi Perumal and Thamarai 2008a). In Nagercoil and the surrounding area, the groundwater quality is in a declining trend because of over exploitation and other anthropogenic activities. So, water quality assessment of present scenario is needed. The objectives of the present study is to carry out a preliminary investigation and interpretation of the groundwater quality in and around Nagercoil town and to demarcate the regions where the groundwater is suitable or unsuitable for both domestic and agricultural purpose based on geochemical and GIS approach.

\section{Study area}

The area chosen for study is located in Kanyakumari district, the southern end of India. The region covers about $30 \mathrm{~km}^{2}$ area in and around Nagercoil city and lies between the longitudes $77^{\circ} 18^{\prime} 30^{\prime \prime} \mathrm{E}-77^{\circ} 34^{\prime} \mathrm{E}$ and $8^{\circ} 4^{\prime} 30^{\prime \prime} \mathrm{N}-$ $8^{\circ} 13^{\prime} 45^{\prime \prime} \mathrm{N}$ latitudes (Fig. 1). In the south, the coast present in a distance of about $6 \mathrm{~km}$ from the study area. Nagercoil is the 12th largest city in the South Indian State of Tamilnadu and a municipality and administrative head quarters of Kanyakumari district. The city is situated closed to the tip of the peninsular India is the southernmost city in the Indian main land. Nagercoil city and its surroundings commonly called as "Nanjilnadu" has an average elevation of about $13 \mathrm{~m}$ above the mean sea level. Sandwiched between the Arabian Sea and the Western Ghats, the city is surrounded by hills, lush green paddy field, and sandy beaches on western sides. Nagercoil has a pleasant, tough humid climate for major part of the year. The average annual rainfall of this district, 70 years is $1,448.6 \mathrm{~mm}$. A general overall view of rainfall pattern recorded in the different rainfall stations indicate that the precipitation varies from 764.30 to $208.30 \mathrm{~mm}$. Most of the rainfall occurs during NE and SE monsoon periods. The contribution of southwest monsoon and northeast monsoon are 37.16 and $37.18 \%$ of the annual rainfall, respectively (Bhagavathi Perumal and Thamarai 2008b). The temperature data indicate higher and lower temperatures prevailed during monsoon period. The average maximum temperature during May is $35.93{ }^{\circ} \mathrm{C}$. The average minimum temperature recorded is $23.85{ }^{\circ} \mathrm{C}$ during January. The annual mean minimum and maximum temperatures are 23.78 and $33.95{ }^{\circ} \mathrm{C}$, respectively (CGWB 2008). The population density in this city is very high. It is about 11,581 peoples per sq.km, according to 2011 census of India.

\section{Geology and hydrogeology}

Geologically, hard rock formations namely granite gneiss and charnockites cover the major part of Kanyakumari district. The rock types present throughout the study area are charnockites, leptinites, leptinite gneiss, granite gneiss, laterites, sandstones, variegated clay, river alluvium, etc. (Fig. 1). The north of northwestern sides of the district is completely occupied by western ghat mountain with a maximum elevation of $1,658 \mathrm{~m}$. The coastal region in the south is a thin strip of plain region having a width of 1-2.5 km (Fig. 2). The coastal line has narrow stretches of beaches and sand dunes. The area adjoining the coast is characterized by laterite cappings. Soil types within the study area are classified into red loams, red lateritic soil, and pale reddish in color. Generally, the mixed types of red and alluvial soil occur within the study area. Commonly, the soils are highly acidic in nature due to massive rainfall and heavy leaching of basic rocks in hilly areas. The thickness of soils in the mountain is almost negligible, whereas it is around $2 \mathrm{~m}$ in the valleys. The sands noticed along the coast are of recent origin.

Charnockites group consists mainly of charnockites, pyroxene granulites, and their associated migmatites. Charnockites also are exposed within the gneisses as bands and lenses. Groundwater occurs in almost all the geologic formations in the district. The groundwater occurrence is limited to only weathered mantle of the hard rock. The groundwater occurrence is limited to $10-35 \mathrm{~m}$ below the ground level with respect to the weathered thickness range. In the bazada and valley-fill area, the water table is very shallow. In alluvial formation, the groundwater occurs 
Fig. 1 Location and geology map of the study area
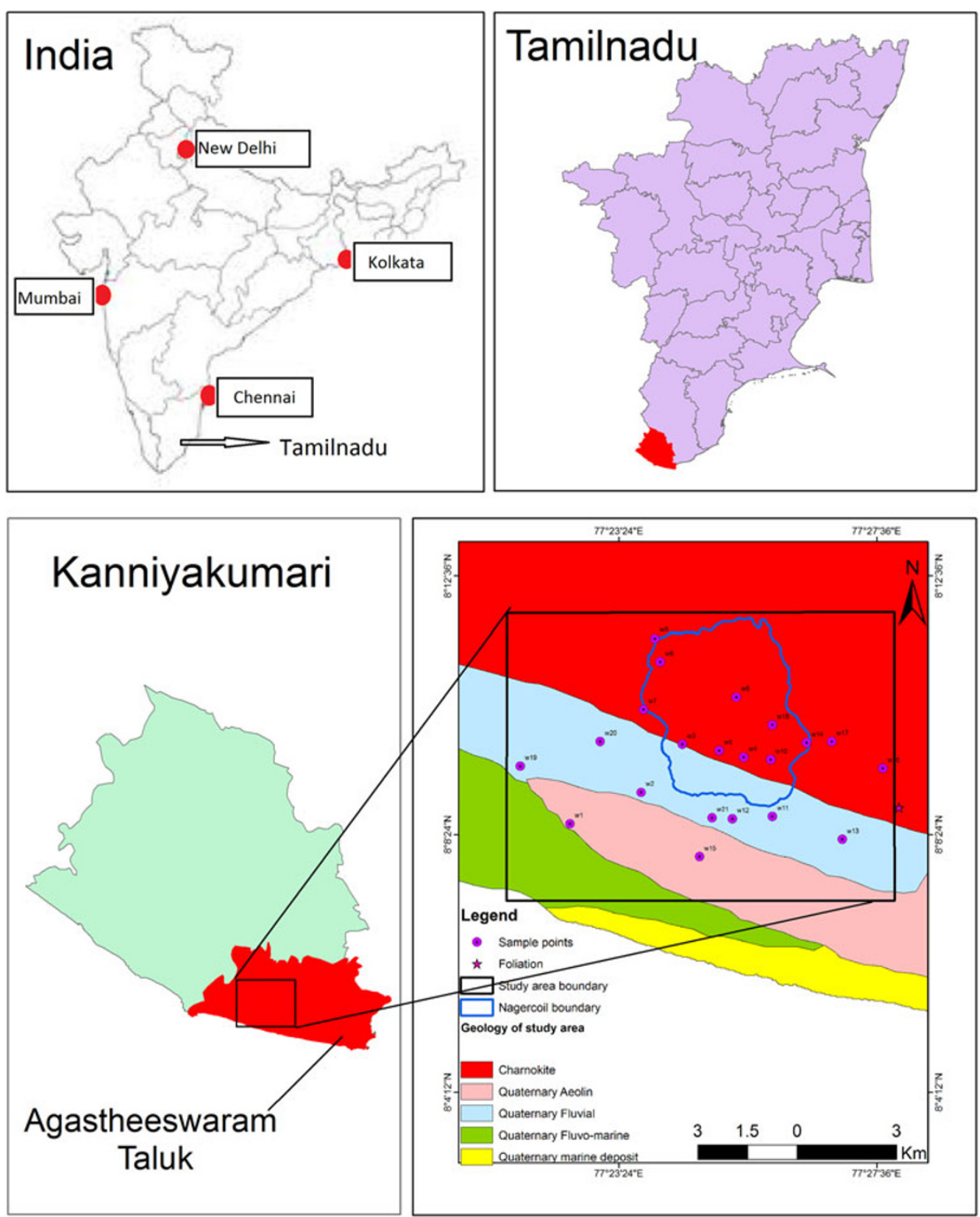

under water table conditions. These formations are highly permeable and porous, and the thickness is very shallow.

Mostly, on hard rock regions, the occurrence of weathered thickness is discontinuous both in space and depth. Hence, the groundwater recharge is influenced by the intensity of weathering. The depth of the wells in the study area varies from 1 to $23 \mathrm{~m}$ below ground level (CGWB 2008). The groundwater level reaches its lowest level in the driest or hottest periods after which it starts rising to reach the highest peak, a little after the end of the rainy seasons. A general overall water level fluctuation suggests the raising during October-December and receding from February to September. A slight rising trend is seen during July because of southwestern monsoon rain. However, general water level conditions during past 10 years are in decreasing trend (PWD 2005).

\section{Materials and methods}

A total of 21 groundwater samples are collected from dug wells and bore wells during January 2012. The samples were collected in the thoroughly acid-washed polyethylene bottle of 11 . During sampling analysis and transportation of water samples to the laboratory, all necessary precautions were taken (Brown et al. 1974). Electrical conductivity (EC) and hydrogen ion concentration $(\mathrm{pH})$ were determined on the field itself using digital meters. Water 
Fig. 2 Geomorphology of the study area

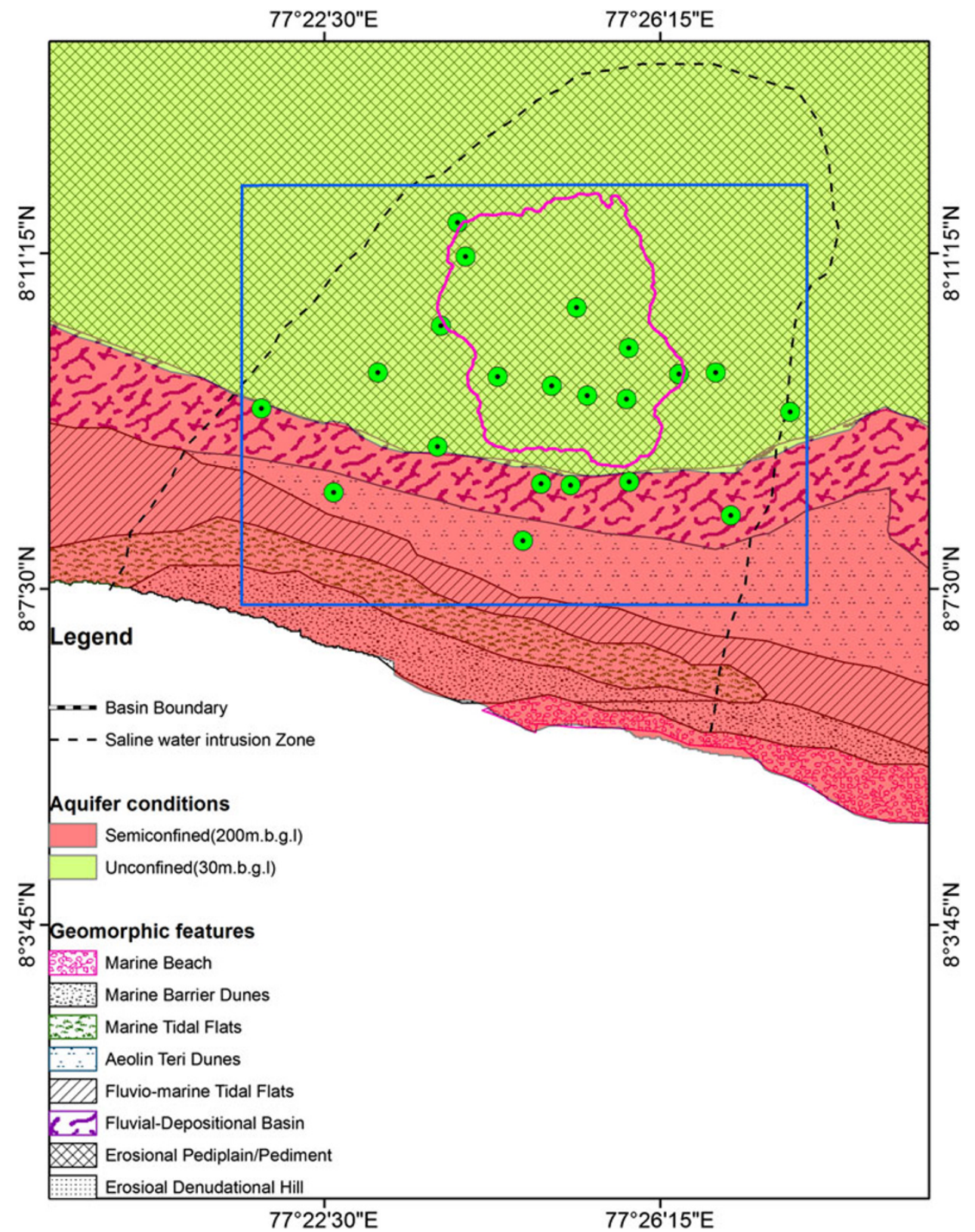

samples were analyzed at the laboratory for chemical constituents, such as calcium, magnesium, chloride, bicarbonate, sodium, potassium, and sulfate by employing standard methods as suggested by the American public health association (APHA 1989). Calcium, magnesium, bicarbonate, and chloride were analyzed using volumetric titration. Ethylene di-amine tetra acetic acid (EDTA) titration was used to estimate the concentration of calcium and magnesium. Bicarbonate concentration was estimated by acid titration $\left(\mathrm{H}_{2} \mathrm{SO}_{4}\right)$. Argentometric titration was used to find the volume of chloride. Flame photometer was used to determine sodium and potassium ions. Sulfate was determined using the spectrophotometer. From the values of the calcium and magnesium ion concentration in groundwater, the total hardness was found out by the following equation (Todd 1980)

$\mathrm{TH}=2.497 \mathrm{Ca}^{2+}+4.115 \mathrm{Mg}^{2+} \mathrm{mg} / \mathrm{l}$.

Total dissolved solids (TDS) were estimated by calculation method. The accuracy of the chemical analysis was verified by calculating ion balance errors, where the errors were generally within $10 \%$ (Mandel and Shiftan 1981). The geochemical data was presented in the graphical charts such as Wilcox's salinity diagram and US salinity diagram to identify the hydrogeochemistry of the groundwater and to evaluate their suitability for agricultural uses. To understand 
Fig. 3 Spatial distribution of total dissolved solids (TDS) in the study area

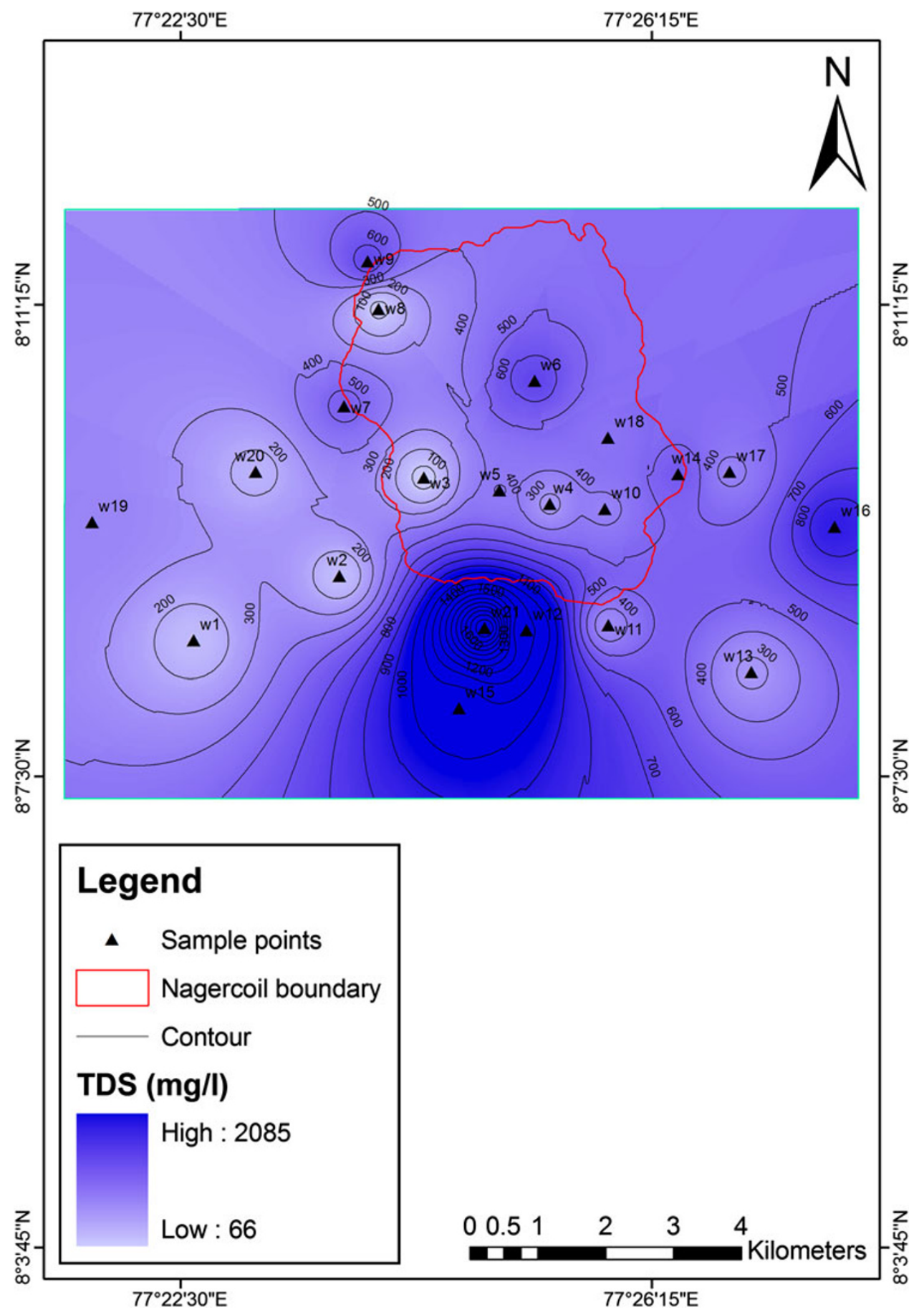

the details of the factors controlling the chemistry of groundwater, Gibb's plots were also constructed.

\section{GIS-modeling}

For creating the spatial distribution maps, GIS has emerged as a powerful tool. GIS can be used for storing, displaying, and analyzing spatial data. By using this data, we can make decisions in several areas including environmental and engineering field (Stafford 1991; Goodchild 1993; Burrough and McDonnell 1998a; Lo and Yeung 2003). The spatial distribution maps were prepared to show the variation in concentrations of the various chemical parameters using inverse distance weighted (IDW) raster interpolation 
Fig. 4 Spatial distribution of total hardness $(\mathrm{TH})$ in the study area

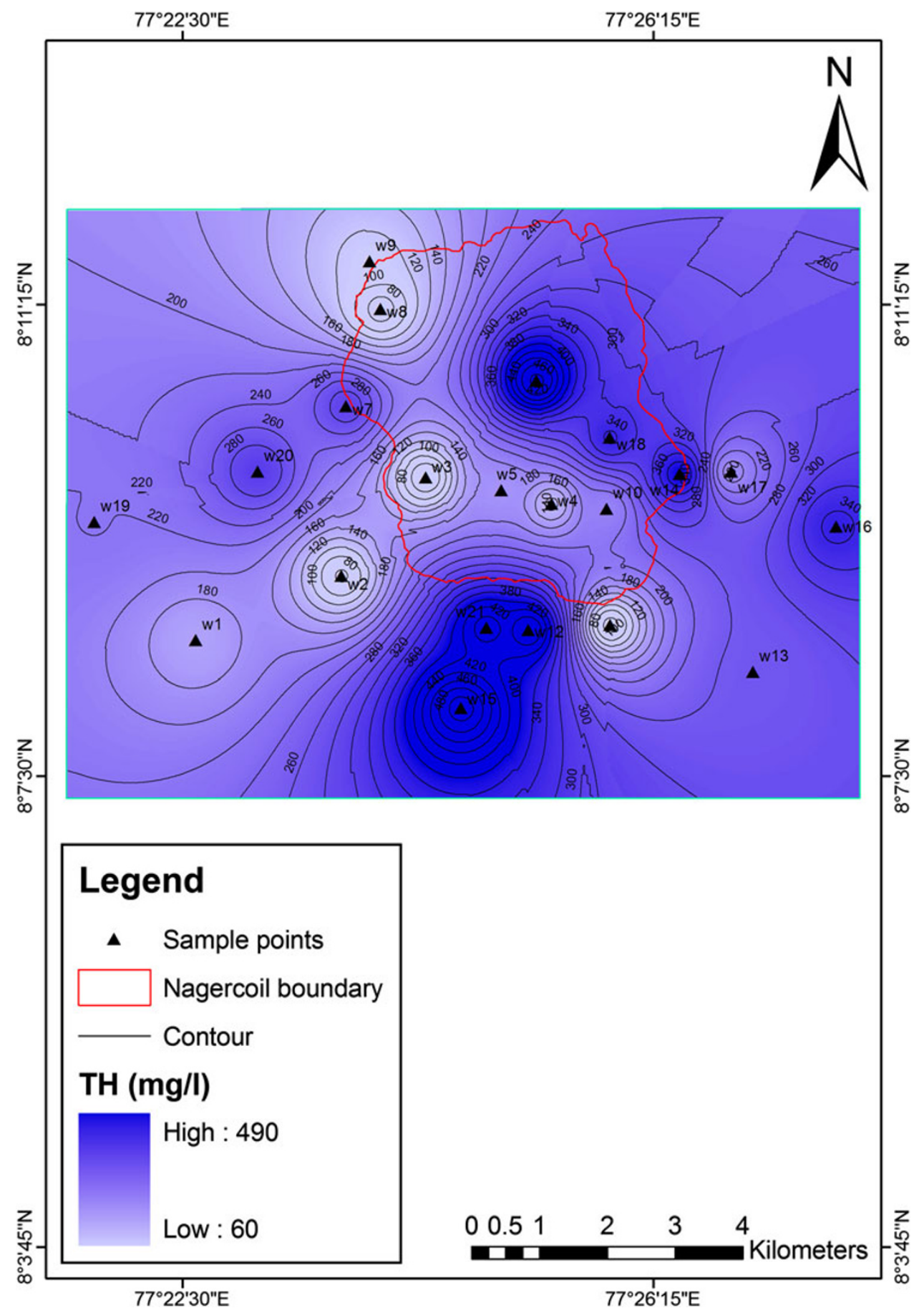

technique of the spatial analyst module in $\operatorname{ArcGIS}^{\circledR} 9.1$. The general formula used in the IDW interpolation method was

$\hat{Z}\left(S_{\mathrm{O}}\right)=\sum_{i=1}^{N} \lambda_{i} Z\left(S_{i}\right)$

where $\hat{Z}\left(S_{\mathrm{O}}\right)$ is the value we are trying to predict for $S_{0}$, $N$ is the number of measured sample points surrounding the prediction location that will be used in the prediction, and $\lambda_{i}$ is the weights assigned to each measured point that we are used here. These weights will decrease with distance; $Z\left(S_{i}\right)$ is the observed value at the location $S_{i}$. When we compare several interpolation techniques, IDW with a squared distance term gives the more consistent results (Burrough and McDonnel 1998a, b; Mathes and Rasmussen 2006) In this study, spatial distribution maps were generated for the selected water quality parameters, namely TDS, TH, $\mathrm{Ca}^{2+}, \mathrm{Mg}^{2+,} \mathrm{SO}_{4}{ }^{2-}, \mathrm{Na}^{+}, \mathrm{K}^{+}, \mathrm{HCO}_{3}{ }^{-}$, and WQI (Figs. 3, 4, 5, 6, 7, 8, 9, 10, 11). 
Fig. 5 Spatial distribution of calcium $\left(\mathrm{Ca}^{2+}\right)$ in the study area

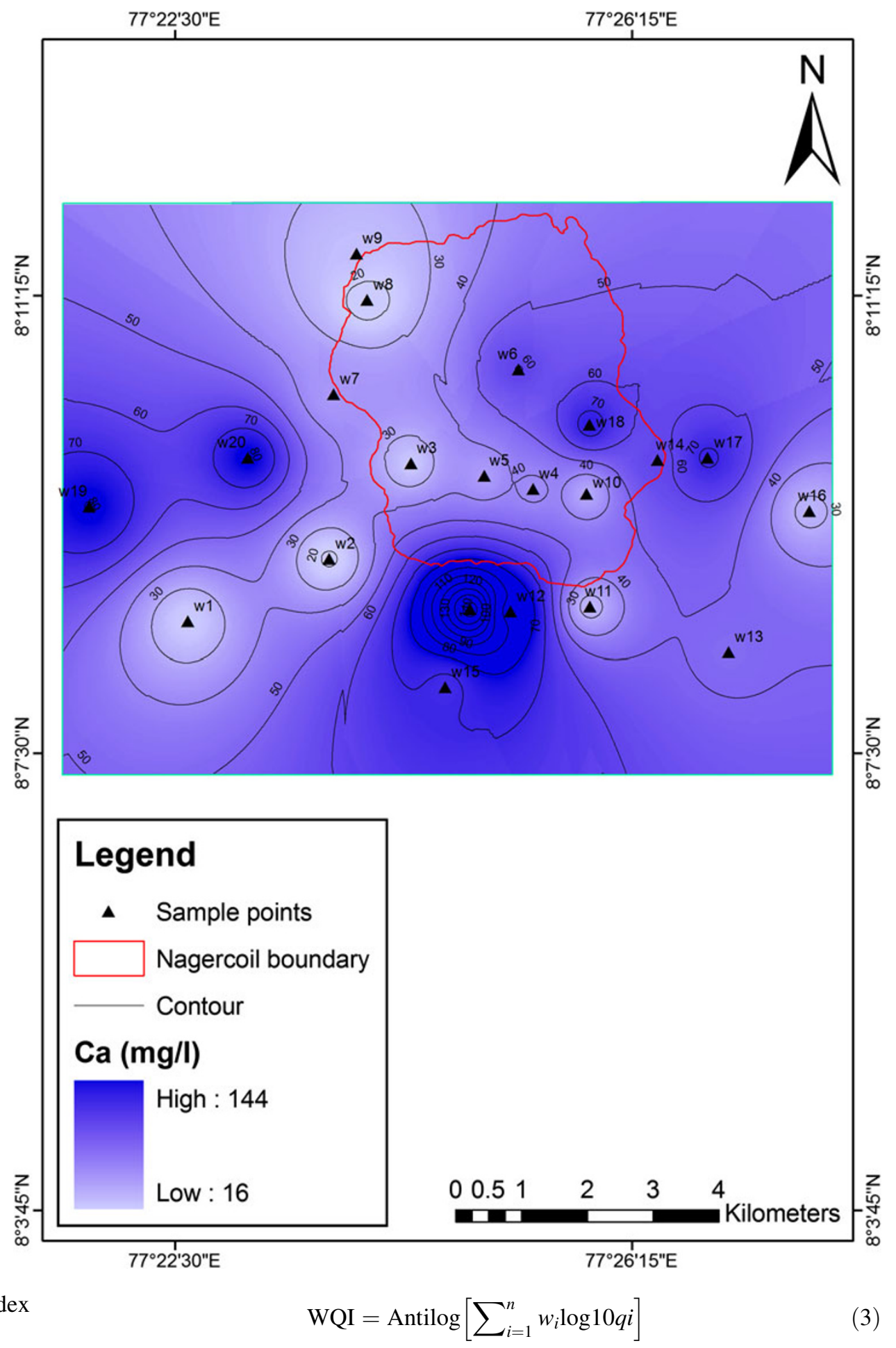

where the weightage factor $\left(w_{i}\right)$ is calculated using the following equation,

$w_{i}=k / s_{n}$

where $k$ is a constant and the value of $k$ and $s_{n}$ is the standard value of $i$ th parameter, et al. 2007), 
Fig. 6 Spatial distribution of magnesium $\left(\mathrm{Mg}^{2+}\right)$ in the study area

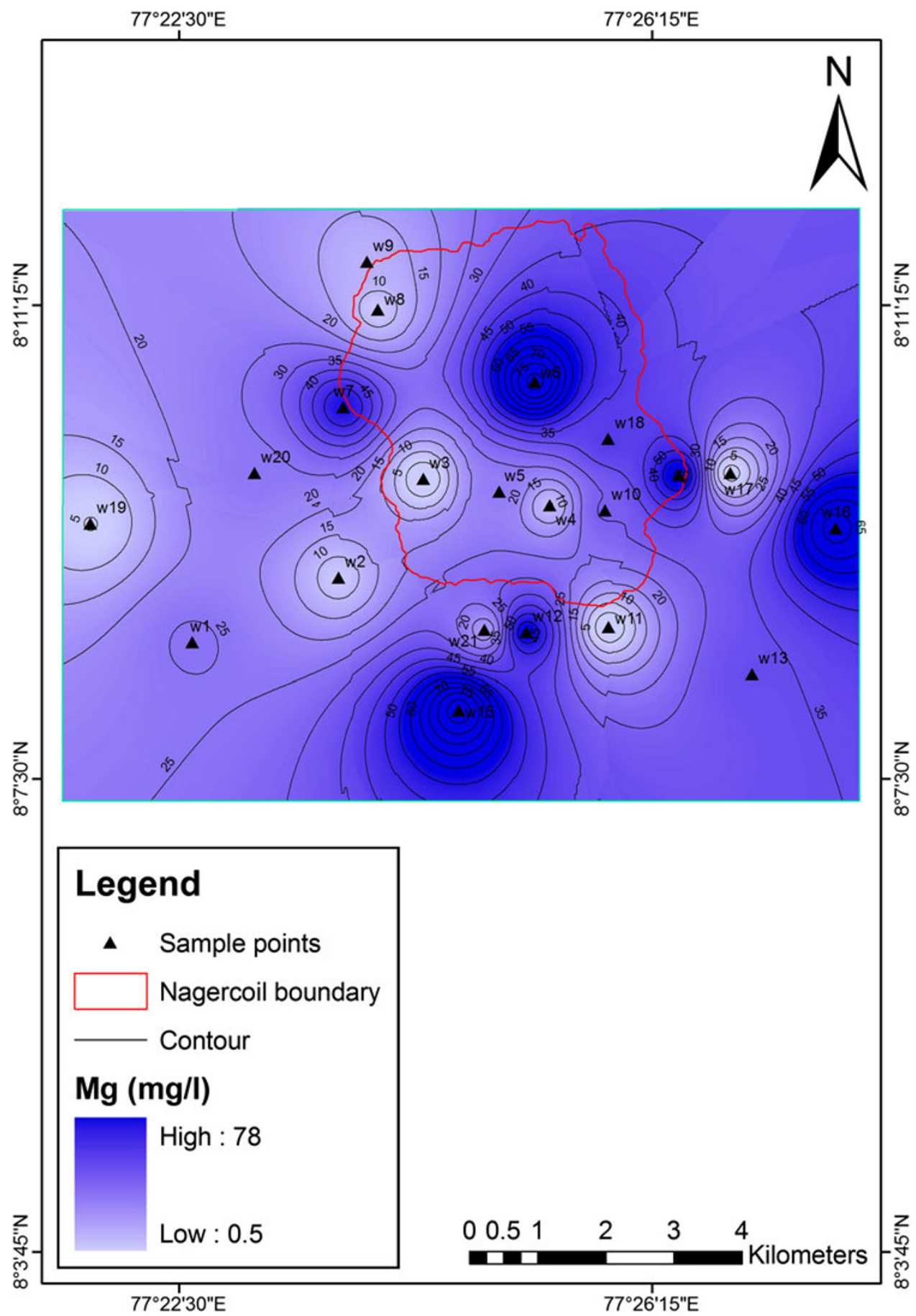

parameter. $v_{\mathrm{s} 1}, v_{\mathrm{s} 2}, \ldots, v_{\mathrm{s} n}$ are the standard values of each parameters obtained from WHO standards of drinking water.

\section{Results and discussion}

Drinking water quality

Suitability of water for various purposes was determined by its quality depending upon the specific standards. The 
Fig. 7 Spatial distribution of sulfate $\left(\mathrm{SO}_{4}{ }^{2-}\right)$ in the study area

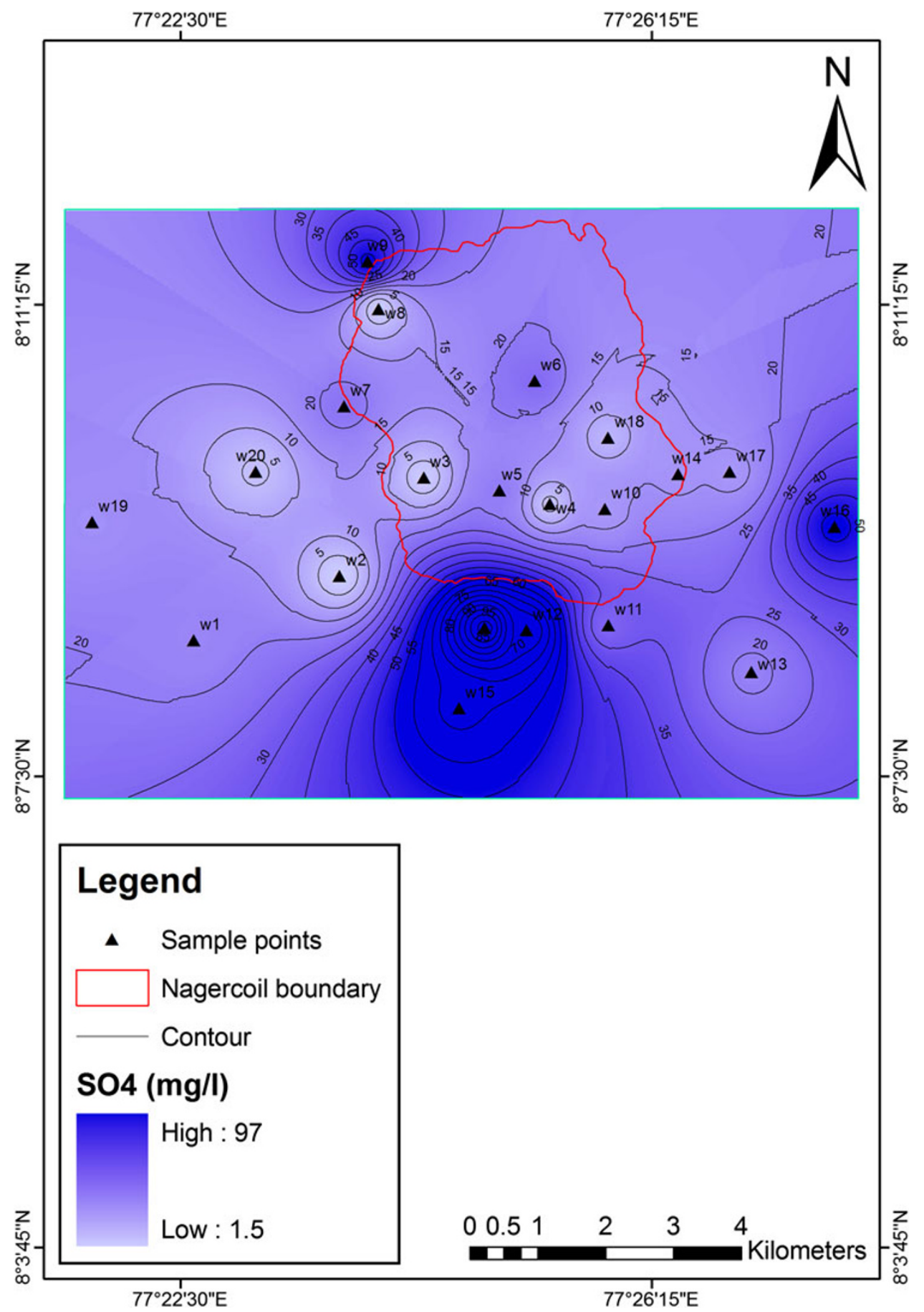

drinking water must be soft, contains low dissolved solids, and must be free from toxic constituents. The drinking water standard derived from standards of World Health Organization (WHO 1997) was used as the standard to determine ground water quality for drinking purposes (Table 1). The ground water is mainly of alkaline nature $(\mathrm{pH}>7)$. The $\mathrm{pH}$ value of ground water in the study area varies between 6.35 and 8.82, with an average of 7.76 , which clearly indicate the alkali nature in most of the groundwater samples. The electrical conductivity at $25^{\circ} \mathrm{C}$ ranges from 104 to $3,260 \mu \mathrm{S} / \mathrm{cm}$ with an average of $818 \mu \mathrm{S} / \mathrm{cm}$. Out of total 21 samples, three of the samples are crossing the maximum permissible limit of $1,500 \mu \mathrm{S} / \mathrm{cm}$ (Table 3). The gastrointestinal irritation in human being may be due to the higher EC content in ground water. Geochemical processes such as ionic exchange, reverse exchange, evaporation, silicate weathering, rock water interaction, sulfate reduction and oxidation processes, and 
Fig. 8 Spatial distribution of sodium $\left(\mathrm{Na}^{+}\right)$in the study area

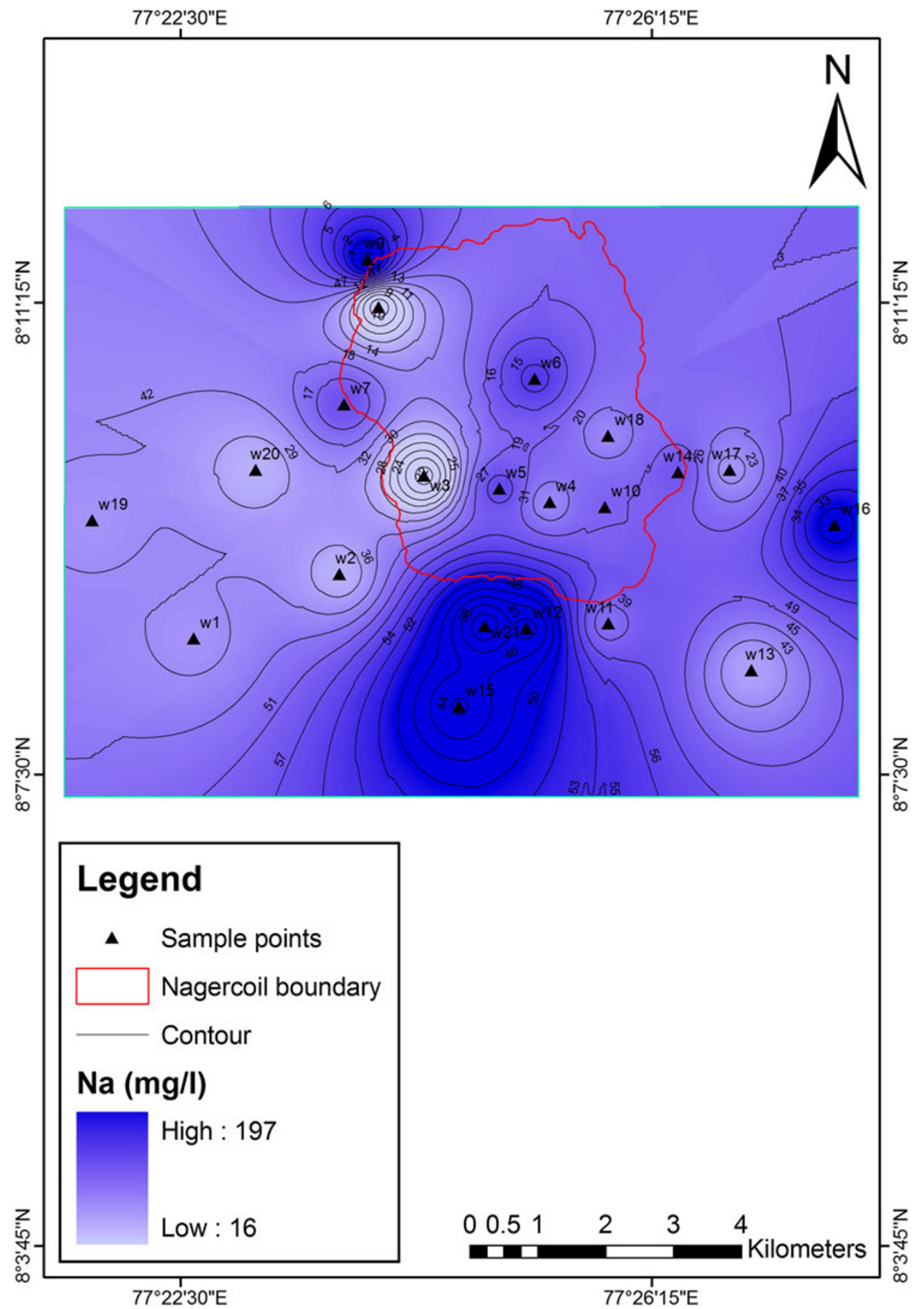

anthropogenic activities are the factors responsible for large variation in EC (Ramesh and Elango 2012).

TDS in the study area is between 67 and 2,086 mg/l with a mean value of $523 \mathrm{mg} / \mathrm{l}$. Based on TDS classification, $71.5 \%$ of wells are having fresh water, which can be permitted for drinking. Remaining $28.5 \%$ wells contain brackish water, which can be used for irrigation only (Freeze and cherri 1979) (Table 3). The dominance of major cations are $\mathrm{Na}^{+}>\mathrm{Ca}^{2+}>\mathrm{Mg}^{2+}>\mathrm{K}^{+}$and the anions dominance are as $\mathrm{HCO}_{3}^{-}>\mathrm{Cl}^{-}>\mathrm{SO}_{4}^{2-}$. The concentration of $\mathrm{Ca}^{2+}$ ion ranges from 16 to $144 \mathrm{mg} / \mathrm{l}$ and the average was $51 \mathrm{mg} / \mathrm{l}$. The $\mathrm{Ca}^{2+}$ limit desirable for drinking water is specified as $75 \mathrm{mg} / \mathrm{l}$ (WHO 1997). Only $19 \%$ of ground water samples in this area exceed the permissible limit. $\mathrm{Mg}^{2+}$ ion concentration in the study area ranges from 1 to $78 \mathrm{mg} / \mathrm{l}$ with an average of $30 \mathrm{mg} / \mathrm{l} ; 23.8 \%$ of samples are crossing the desirable limit $50 \mathrm{mg} / 1 . \mathrm{Ca}^{2+}$ and $\mathrm{Mg}^{2+}$ ions present in the ground water may be due to the 
Fig. 9 Spatial distribution of potassium $\left(\mathrm{K}^{+}\right)$in the study area

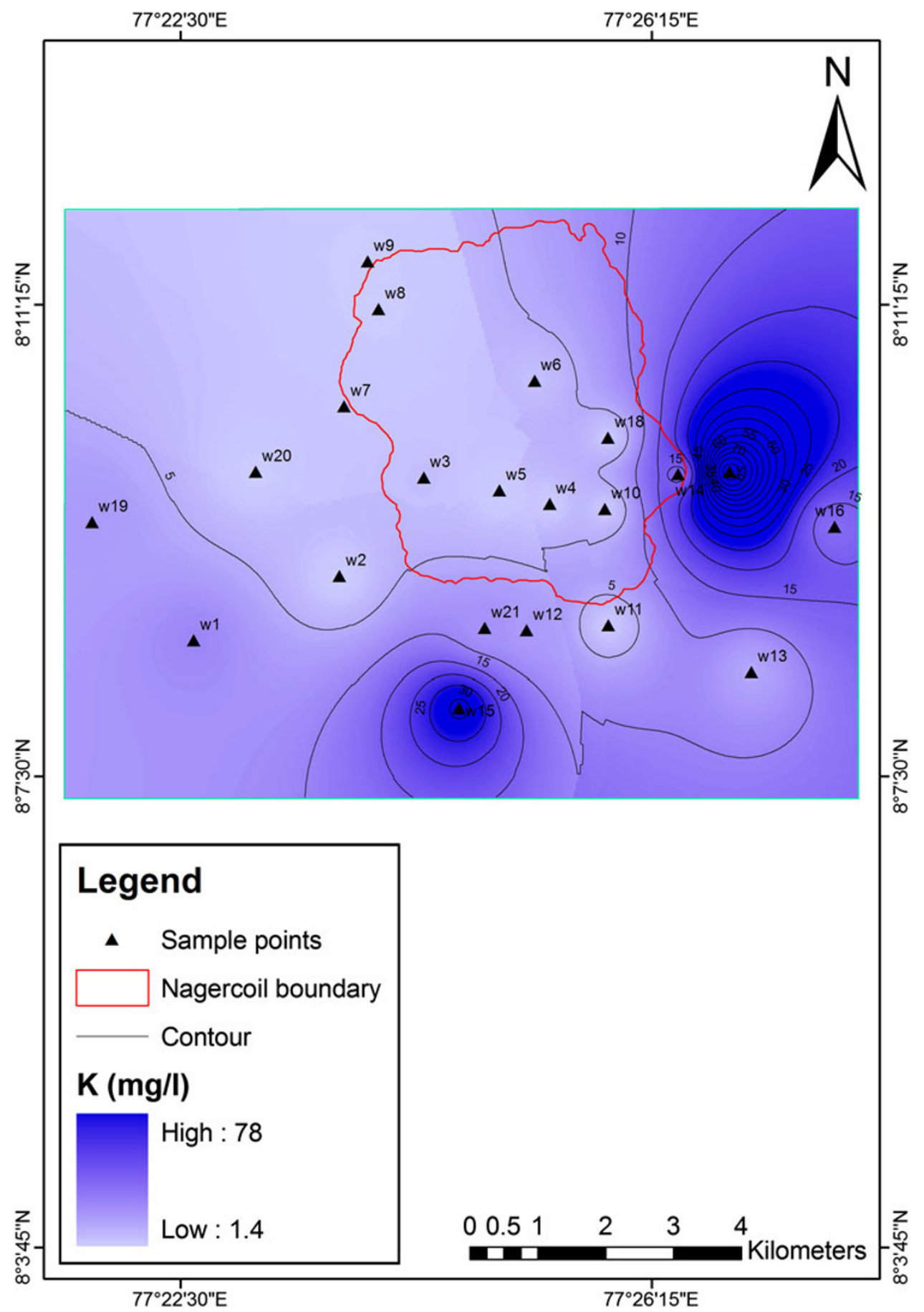

leaching process of limestone, dolomites, gypsum, and anhydrites (Garrels 1976). The low values of $\mathrm{Ca}^{2+}$ and $\mathrm{Mg}^{2+}$ may be due to the reverse cationic exchange with sodium, i.e., sodium ions replace $\mathrm{Ca}^{2+}$ and $\mathrm{Mg}^{2+}$ ions there by reducing concentration (Thomson Jacob et al. 1999).

Due to the presence of divalent metallic cations, $\mathrm{Ca}^{2+}$ and $\mathrm{Mg}^{2+}$, the hardness may arise. The total hardness of the samples lies between 60 and $490 \mathrm{mg} / \mathrm{l}$ with an average of $240 \mathrm{mg} / \mathrm{l} .33 \%$ of the entire ground water samples have total hardness exceeding the safe limits of $300 \mathrm{mg} / \mathrm{l}$, which is the maximum permissible limit for the drinking water (Table 3). The property of hardness increases the boiling point of water, and it can prevent the formation of lather and soap. However, it has no noticeable adverse effect on human health. The health problems such as urolithiasis, anencephaly, prenatal mortality, some type of cancer, and cardiovascular disorders may get increased due to the longterm usage of very high hard water (Agarwal and Jagetai 
Fig. 10 Spatial distribution of bi-carbonate $\left(\mathrm{HCO}_{3}{ }^{-}\right)$in the study area

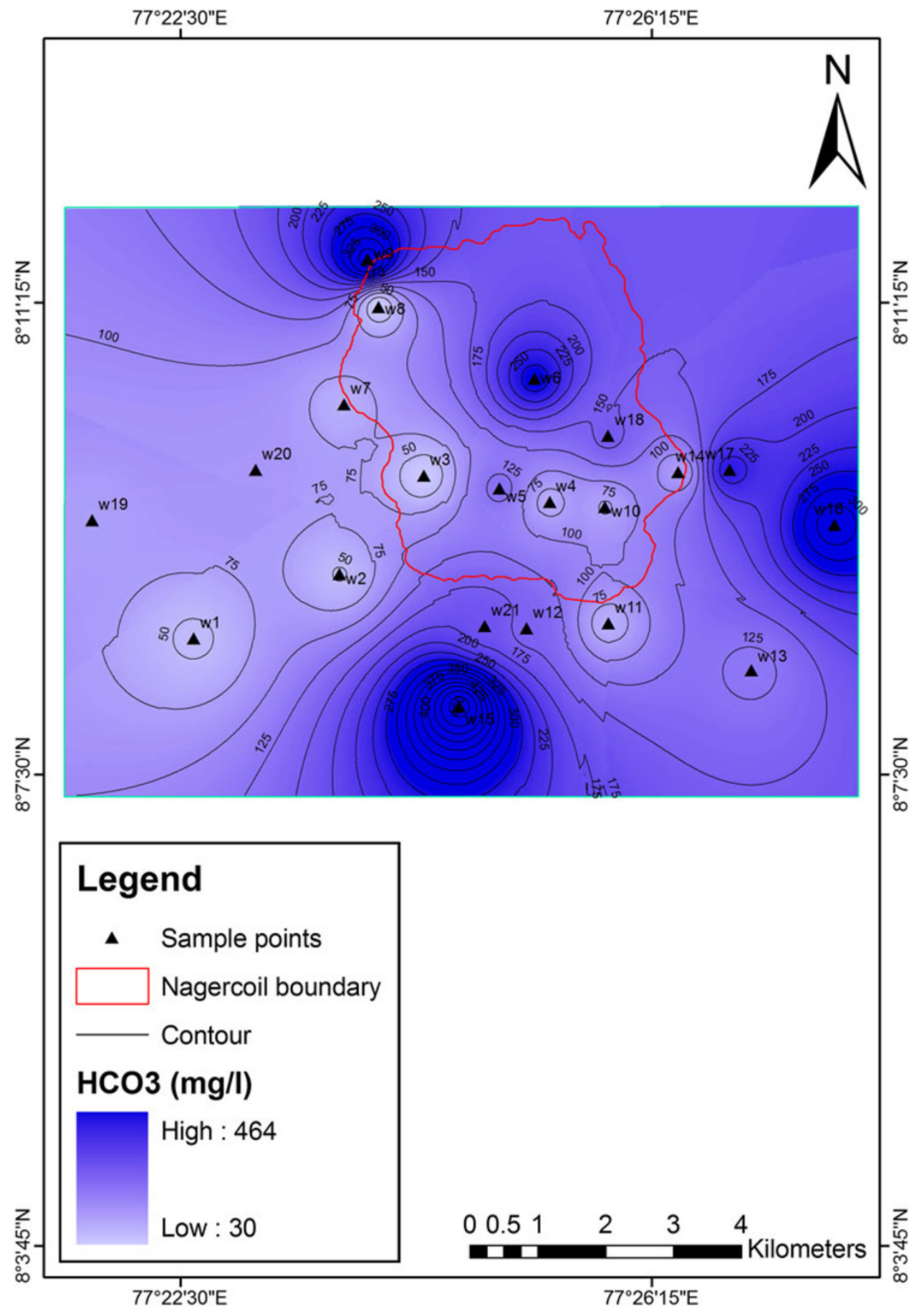

1997; Durvey et al. 1991). The recommended maximum permissible limit for the sodium concentration in drinking water is $200 \mathrm{mg} / \mathrm{l}$. The sodium concentration in ground water samples ranges from 16 to $197 \mathrm{mg} / \mathrm{l}$ with an average value of $103 \mathrm{mg} / \mathrm{l}$. None of the samples are exceeding the maximum permissible limit, but $90 \%$ of samples indicate that they are beyond the desirable limit $50 \mathrm{mg} / \mathrm{l}$. The presence of higher sodium in ground water may cause hypertension, congenial heart disease, and kidney problems during our intake (Raju et al. 2011). The chemical data from the ground water samples reveals that $62 \%$ of samples are exceeding both desirable and permissible limit for sodium. The potassium $\left(\mathrm{K}^{-}\right)$values in the groundwater samples are recorded between 1.4 and $78 \mathrm{mg} / \mathrm{l}$ with an average of $9 \mathrm{mg} / \mathrm{l} .19 \%$ of the total samples are crossing the permissible limit of $12 \mathrm{mg} / \mathrm{l}$ of potassium in the groundwater. The presence of silicate minerals in the groundwater from the igneous and metamorphic rocks may 
Fig. 11 Spatial distribution of Water Quality Index (WQI) in the study area

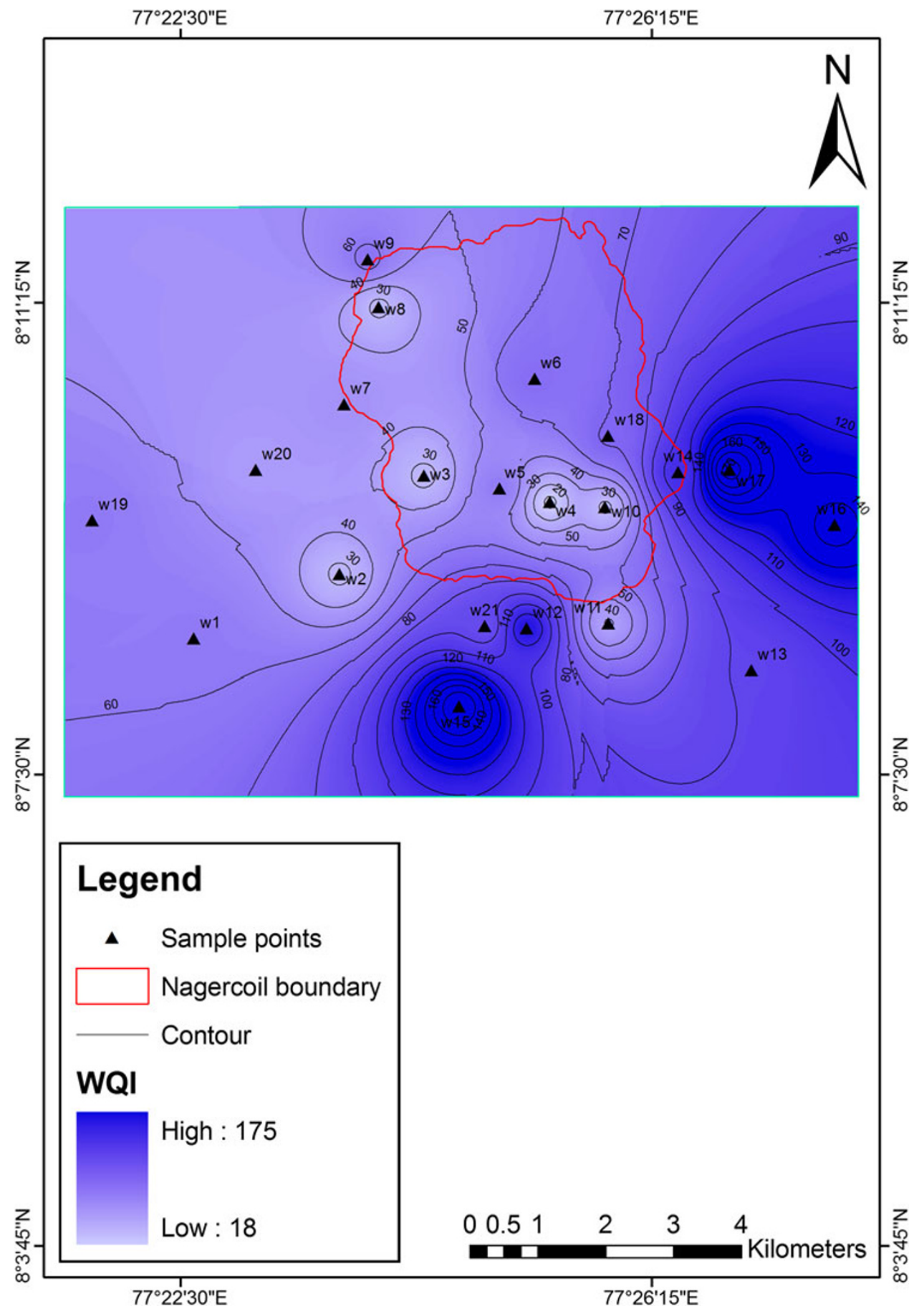

increase the concentration of potassium in the groundwater (Karnath 1987). The excessive use of potassium for cultivation might have percolated into the groundwater also increases the potassium content in groundwater (Jameel and Hussain 2011).

The most dominant ion in the ground water was $\mathrm{HCO}_{3}{ }^{-}$, in our study area. The value of $\mathrm{HCO}_{3}{ }^{-}$lies between 30 and $463 \mathrm{mg} / \mathrm{l}$ with an average of $142 \mathrm{mg} / \mathrm{l}$. Three of the total samples exceed the permissible limit $(300 \mathrm{mg} / \mathrm{l})$ in our study area. No known adverse health effects are noticed on human beings because of bicarbonate ion. $19 \%$ of ground water samples indicate the higher chloride concentration exceeding the maximum allowable limit. The higher concentrations of chloride in the groundwater may be because of the percolation of domestic sewage and irrigated land water (Bhatia 1998). High concentrations of chloride in drinking water give a salty taste to the water and produce a laxative effect on people not habituated to it. $\mathrm{SO}_{4}{ }^{2-}$ 
Table 1 Results of chemical analysis and range of the obtained parameters compared with WHO (1997) drinking water Standards

\begin{tabular}{|c|c|c|c|c|c|}
\hline \multirow{2}{*}{$\begin{array}{l}\text { Chemical } \\
\text { parameters }\end{array}$} & \multicolumn{2}{|c|}{ Concentrations of ions } & \multirow{2}{*}{$\begin{array}{l}\text { Ranges of standards } \\
\text { [WHO (1997)] } \\
\text { (Desirable to } \\
\text { permissible) }\end{array}$} & \multirow{2}{*}{$\begin{array}{l}\text { Samples exceeding } \\
\text { desirable limits }\end{array}$} & \multirow{2}{*}{$\begin{array}{l}\text { Percentage of } \\
\text { samples }\end{array}$} \\
\hline & Range & Mean & & & \\
\hline $\mathrm{pH}$ & $6.35-8.82$ & 7.69 & $7.0-9.2$ & w1, w2, w10, w19 & 19.1 \\
\hline $\mathrm{EC}(\mu \mathrm{S} / \mathrm{cm})$ & $104-3,260$ & 818 & $500-1,500$ & w12, w15, w21 & 14.3 \\
\hline TDS $(\mathrm{mg} / \mathrm{l})$ & $67-2,086$ & 503 & $500-1,500$ & w6, w7, w9, w12, w14, w15, w16, w21 & 38.2 \\
\hline $\mathrm{Ca}^{2+}(\mathrm{mg} / \mathrm{l})$ & $16-144$ & 49.4 & $75-200$ & w12, w19-w21 & 19.1 \\
\hline $\mathrm{Mg}^{2+}(\mathrm{mg} / \mathrm{l})$ & $0.6-77.8$ & 28.2 & $30-150$ & w6, w7, w10, w12-w16, w18 & 42.8 \\
\hline $\mathrm{Na}^{+}(\mathrm{mg} / \mathrm{l})$ & 16-197 & 99 & $50-200$ & w1, w2, w4-w7, w9-w21 & 90.6 \\
\hline $\mathrm{K}^{+}(\mathrm{mg} / \mathrm{l})$ & $1.4-78$ & 9 & $10-12$ & w14-w17 & 19.1 \\
\hline $\mathrm{HCO}_{3}^{-}(\mathrm{mg} / \mathrm{l})$ & $31-464$ & 137 & $300-600$ & w9, w15, w16 & 14.3 \\
\hline $\mathrm{SO}_{4}^{-}(\mathrm{mg} / \mathrm{l})$ & $1.5-97$ & 25 & $200-600$ & - & - \\
\hline $\mathrm{Cl}^{-}(\mathrm{mg} / \mathrm{l})$ & 16-905 & 160 & $250-600$ & w12, w15, w16, w21 & 19.1 \\
\hline $\mathrm{TH}(\mathrm{mg} / \mathrm{l})$ & $60-490$ & 240 & $100-500$ & w1, w4-w7, w9, w10, w12-w21 & 80.9 \\
\hline
\end{tabular}

concentration in the study area ranges from 1.5 to $97 \mathrm{mg} / \mathrm{l}$. Higher concentration of sulfate in drinking water may cause respiratory problems (Maiti 1982).A higher sulfate content also may have a laxative effect with excess of magnesium and also causes corrosion of metals in the distribution system if the water had low alkaline (Raju et al. 2011).

\section{Water quality index}

The water quality of the study area was found using the WQI which is a combined parameter which gives an equal importance to all the parameters which we considered. The classification based on WQI is presented in Table 2. From the WQI, we have found that $38 \%$ of the total samples fall in the suitable limit for drinking, whereas $29 \%$ of the total groundwater samples get moderately polluted. The remaining $33 \%$ of samples were not suitable for drinking. In the sampling stations, $12,15,16$, and 17 located on the south and east of the study area were highly polluted when compared with the other stations. The sewage water and the indiscriminate use of huge amount of fertilizer in the surrounding agricultural lands may be the reason for the pollution of groundwater (Adhikary et al. 2012) in the study area.

Table 2 Classification based on water quality index

\begin{tabular}{lllll}
\hline WQI & Classification & Sample numbers & $\begin{array}{l}\text { Total no. } \\
\text { of samples }\end{array}$ & Percentage \\
\hline$<50$ & Suitable & $2-4,7,8,10,11,20$ & 8 & 38.2 \\
$50-80$ & $\begin{array}{c}\text { Moderately } \\
\text { polluted }\end{array}$ & $1,5,6,9,18,19$ & 6 & 28.5 \\
& $\begin{array}{c}\text { Severely } \\
\text { polluted }\end{array}$ & $12-17,21$ & 7 & 33.3 \\
& & & \\
\hline
\end{tabular}

كدينة الملك عبدالعزين KACST
Irrigation water quality

The ground water suitability for irrigation is contingent on the effects of their mineral constituent in water on both soil and plants (Richards 1954). An important factor which relates the crop growth with water quality is drainage. If a soil is well drained, crops may grow on it, even if it has a generous amount of saline water. On the other hand, in poorly drained area but having good quality water may fail to produce satisfactory yield (Todd 1980). For determining the irrigation water quality, some important hydrochemical parameters such as EC, salinity, percent sodium, sodium adsorption ratio (SAR), residual sodium carbonate (RSC), permeability index (PI), Kelly's index (KI), and magnesium ratio (MR) are used.

\section{Salinity and alkalinity hazard}

High electrical conductivity represents the elevated salt content on water. In irrigation water, high salinity leads to formation of saline soils, which is the major cause of loss in production in irrigation lands. It also has adverse environmental impacts on irrigation. Based on EC values, Richards (1954) classified the groundwater for irrigation into four classes. According to the classification, $62 \%$ of samples are excellent to good; the remaining $38 \%$ of samples are medium and bad in salinity. SAR is a measure of sodium/ alkali hazards to crops. Sodium ion's relative activity with soil is expressed in terms of the sodium absorption ratio. The SAR is calculated as follows (Karnath 1987):

$\mathrm{SAR}=\frac{\mathrm{Na}^{+}}{\sqrt{\mathrm{Ca}^{2+}+\mathrm{Mg}^{2+} / 2}}$

where all concentrations are expressed in meq/l.

Classification of water samples in the study area according to SAR values is done (Table 3). The SAR value in the 
Table 3 Classification based on different chemical parameters

\begin{tabular}{|c|c|c|c|c|}
\hline Parameters & Classification & Sample numbers & $\begin{array}{l}\text { Total no. of } \\
\text { samples }\end{array}$ & Percentage \\
\hline \multicolumn{5}{|c|}{$\mathrm{EC}(\mu \mathrm{S} / \mathrm{m})(\mathrm{Wilcox} 1955)$} \\
\hline$<250$ & Low & $1-3,8,20$ & 5 & 23.8 \\
\hline $250-750$ & Medium & $4,5,10,11,13,17-19$ & 8 & 38.2 \\
\hline $750-2,250$ & High & $6,7,9,12,14-16$ & 7 & 33.3 \\
\hline$>2,250$ & Very high & 21 & 1 & 4.7 \\
\hline \multicolumn{5}{|c|}{ TDS (mg/l) (USGS 2000) } \\
\hline$<500$ & Desirable for drinking & $1-4,8,13,20$ & 7 & 33.3 \\
\hline $500-1,000$ & Permissible for drinking & $5,7,10,11,14,17-19$ & 8 & 38.2 \\
\hline $1,000-3,000$ & Useful for irrigation & $6,9,12,15,16,21$ & 6 & 28.5 \\
\hline$>3,000$ & Unfit for drinking and irrigation & - & - & - \\
\hline \multicolumn{5}{|c|}{ TH (mg/l) (Sawyer et al. 2003) } \\
\hline$<75$ & Soft & $3,8,11$ & 3 & 14.3 \\
\hline $75-150$ & Moderately hard & $2,4,9$ & 3 & 14.3 \\
\hline $150-300$ & Hard & $1,5,7,10,13,17,19,20$ & 8 & 38.1 \\
\hline$>300$ & Very hard & $6,12,14-16,18,21$ & 7 & 33.3 \\
\hline \multicolumn{5}{|c|}{ SAR (Richards 1954) } \\
\hline $0-6$ & No problems & $1-8,10,12-21$ & 19 & 90.6 \\
\hline 9-Jun & Increase problems & 11 & 1 & 4.7 \\
\hline$>9$ & Severe problems & 9 & 1 & 4.7 \\
\hline \multicolumn{5}{|c|}{ RSC (meq/l) (Richards 1954) } \\
\hline$<1.25$ & Good & $1-8,10-14,18-21$ & 17 & 80.9 \\
\hline $1.25-2.5$ & Doubtful & - & - & - \\
\hline$>2.5$ & Unsuitable & $9,15-17$ & 4 & 19.1 \\
\hline
\end{tabular}

study area ranges from 1.2 to 9.6 with an average of 4.2 . Expect two samples all other are in the low sodium region (S1). Only one sample (Well no. 9) is crossing the limit 6-9. In such cases, the irrigation water will cause permeability problems on shrinking and swelling types of clayey soils (Saleh et al. 1999). United States salinity diagram (Wilcox 1948) was obtained by plotting the correlation between SAR and electrical conductivity (Fig. 12). It was found that $19 \%$ of samples fall in the $\mathrm{C} 1-\mathrm{S} 1$ region, which indicates low salinity and low alkalinity hazard region. $43 \%$ of samples fall in the medium salinity and low alkalinity region $\mathrm{C} 2-\mathrm{S} 1$. $23.8 \%$ of samples are in the region $\mathrm{C} 3-\mathrm{S} 1$, which indicates high salinity with low alkalinity. Only two of the samples are falling in the region $\mathrm{C} 3-\mathrm{S} 2$ and $\mathrm{C} 4-\mathrm{S} 2$ one each, respectively. Generally, the study area indicates low to high salinity and low to medium alkalinity water, which can be used for irrigation in almost all types of soils with a little danger of exchangeable sodium.

\section{$\mathrm{Cl}^{-} / \mathrm{HCO}_{3}{ }^{-}$ratio}

The salinization amount in the groundwater can be classified using the $\mathrm{Cl}^{-} / \mathrm{HCO}_{3}{ }^{-}$ratios (Revelle 1941). The $\mathrm{Cl}^{-}$/ $\mathrm{HCO}_{3}{ }^{-}$ratio was computed for the groundwater samples of the study area and given in Table $4.19 .1 \%$ of the

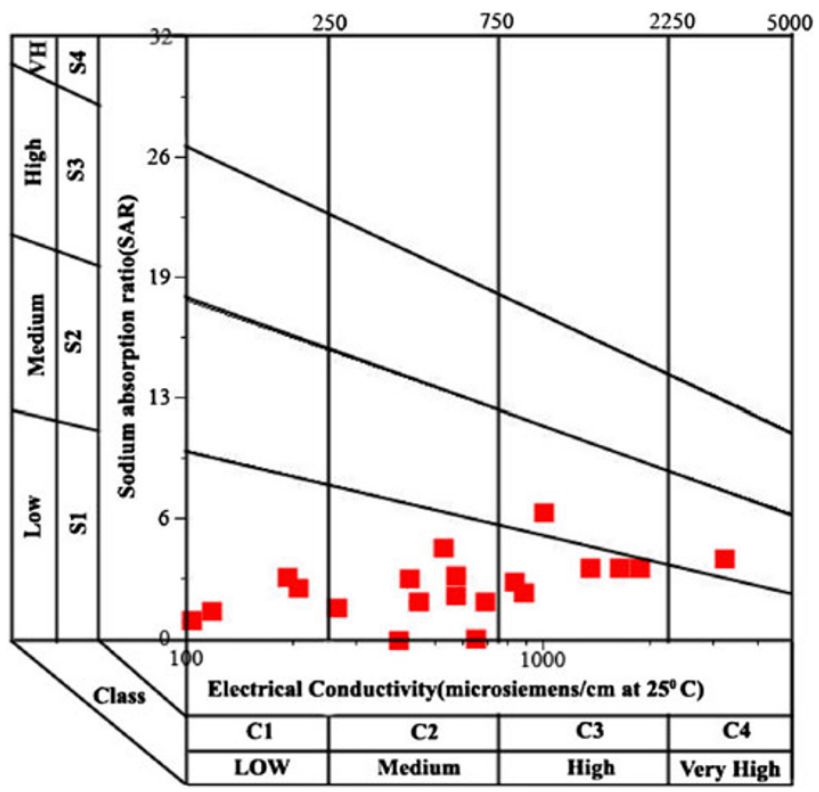

Fig. 12 Rating of groundwater samples on relation to salinity hazard and sodium hazard

groundwater samples in the study area having less than 0.5 $\mathrm{Cl}^{-} / \mathrm{HCO}_{3}^{-}$ratios are not affected by salinization. All the other groundwater samples in the study area are in slight to 
Table 4 Classification based on $\mathrm{Cl}^{-} / \mathrm{HCO}_{3}{ }^{-}$values (Revelle 1941)

\begin{tabular}{|c|c|c|c|c|}
\hline $\begin{array}{l}\mathrm{Cl}^{-} / \\
\mathrm{HCO}_{3}^{-} \\
\text {ratio }\end{array}$ & Classification & $\begin{array}{l}\text { Sample } \\
\text { numbers }\end{array}$ & $\begin{array}{l}\text { Total no. of } \\
\text { samples }\end{array}$ & Percentage \\
\hline$<0.5$ & Not affected & $9,17,19,20$ & 4 & 19.1 \\
\hline $0.5-6.6$ & $\begin{array}{l}\text { Slightly to } \\
\text { moderately } \\
\text { affected }\end{array}$ & $\begin{array}{c}1-8,10-16 \\
18,21\end{array}$ & 17 & 80.9 \\
\hline$>6.6$ & Severely affected & - & - & - \\
\hline
\end{tabular}

moderate salinity affected range. However, the values of $\mathrm{Cl}^{-} / \mathrm{HCO}_{3}{ }^{-}$high in some stations do not indicate the seawater intrusion. It may be due to some other anthropogenic activities such as intrusion from domestic sewage or possibly due to uncontrolled agricultural practices.

\section{$\%$ Sodium}

Sodium concentration in groundwater is a very important parameter in determining the irrigation quality. The formula used for calculating the sodium percentage was

$\mathrm{Na} \%=\left(\mathrm{Na}^{+}+\mathrm{K}^{+}\right) /\left(\mathrm{Ca}^{2+}+\mathrm{Mg}^{2+}+\mathrm{K}^{+}+\mathrm{Na}^{+}\right) \times 100$

where all the ionic concentrations are in meq/l.

The determined valued of sodium percentage lies between 31.7 and 76.5 (Table 5). The maximum allowable limit of sodium percentage in groundwater is $60 \%$ (Ramakrishna 1998). The percentage sodium and electrical conductance are correlated by Wilcox as shown in Fig. 13. Wilcox's diagram shows that only three samples are crossing the permissible limit. One of them, i.e., W21 is unsuitable for irrigation due to its high EC content (Wilcox 1955). In irrigation water if the sodium concentration became high, sodium ions tends to replace the $\mathrm{Mg}^{2+}$ and $\mathrm{Ca}^{2+}$ ions by absorbed clay particles. This exchange process in soil reduces the permeability and eventually decreases the internal drainage of the soil. Hence, water and air circulation is restricted during wet conditions, and such soils become hard in dry conditions (Collins and Jenkins 1996; Saleh et al. 1999; Subramani et al. 2005). Chemical weathering of rock forming minerals, dissolution-precipitation of secondary carbonates, and ion exchange between water and clay minerals are some of the general reactions responsible for the geochemical constitution of the groundwater. Dissolution of both primary silicate and carbonate minerals may lead to the increase of calcium, sodium, magnesium, and bicarbonate, which increase the value of $\mathrm{pH}$ (Rouabhia et al. 2011). The higher concentrations of sodium and chlorine in groundwater are probably controlled by rock water interaction most likely by feldspar weathering. The low sodium in some of the
Table 5 Classification of groundwater based on \% Na values (Wilcox 1955)

\begin{tabular}{|c|c|c|c|c|}
\hline $\begin{array}{l}\% \mathrm{Na} \\
\text { (after } \\
\text { Wilcox } \\
1955 \text { ) }\end{array}$ & Classification & Sample numbers & $\begin{array}{l}\text { Total } \\
\text { no. of } \\
\text { samples }\end{array}$ & Percentage \\
\hline$<20$ & Excellent & - & - & \\
\hline $20-40$ & Good & $3,6,13,14,18,20$ & 6 & 28.5 \\
\hline $40-60$ & Permissible & $\begin{array}{c}1,4,5,7,8,10,12 \\
15-17,19,21\end{array}$ & 12 & 57.2 \\
\hline $60-80$ & Doubtful & $2,9,11$ & 3 & 14.3 \\
\hline$>80$ & Unsuitable & _- & - & - \\
\hline
\end{tabular}

samples is due to the ion exchange with calcium and magnesium in clays, which is common in saline groundwater (Cartwright et al. 2004).

\section{Chloroalkaline indices}

Chloroalkaline indices 1 and 2 are used to understand the chemical reactions in which ion exchange takes place (Swarna Latha and Nageswara Rao 2012). Ions in groundwater exchange with the ions of its aquifer environment during the periods of residence and movement. They are calculated as follows:

$$
\begin{aligned}
& \mathrm{CAI} 1=\left[\mathrm{Cl}^{-}-\left(\mathrm{Na}^{+}+\mathrm{K}^{+}\right)\right] / \mathrm{Cl}^{-} \\
& \mathrm{CAI} 2=\left[\mathrm{Cl}^{-}-\left(\mathrm{Na}^{+}+\mathrm{K}^{+}\right)\right] /\left(\mathrm{SO}_{4^{2-}}+\mathrm{HCO}_{3^{-}}+\mathrm{CO}_{3^{2-}}+\mathrm{NO}_{3^{-}}\right)
\end{aligned}
$$

where the concentration of ions are in meq/l.

Both the above indices are negative if there is an exchange between calcium or magnesium in the groundwater with sodium and potassium in the aquifer material, and both these indices will be positive if there is a reverse ion exchange (Schoeller 1977). The obtained results point out that most of the samples in the study area (14 wells) display positive and some wells (7 wells) show negative. This observation indicates that the reverse ion exchange is the leading process in the groundwater, whereas normal ion exchange is also observed in some wells during the study.

\section{Residual sodium carbonate}

High concentration of bi-carbonates in groundwater increases the precipitation of calcium and magnesium as carbonates. To qualify this effect in groundwater an (Eaton 1950). RSC can be calculated as follows (Regunath 1987):

$\mathrm{RSC}=\left(\mathrm{HCO}_{3}^{-}+\mathrm{CO}_{3}^{2-}\right)-\left(\mathrm{Ca}^{2+}+\mathrm{Mg}^{2+}\right)$

all the concentrations are expressed in meq/l.

The classification of irrigation water based on the RSC values is presented (Table 3), where $80 \%$ of samples are good and remaining $20 \%$ are unsuitable for irrigation. 
Fig. 13 Suitability of groundwater for irrigation in Wilcox diagram

\section{Kelley's ratio}

Kelley's ratio was used to classify the irrigation water quality (Kelley 1940), which is the level of $\mathrm{Na}^{+}$measured against calcium and magnesium. The formula for calculating the Kelley's ratio is as follows:

$\mathrm{KR}=\frac{\mathrm{Na}^{+}}{\left(\mathrm{Ca}^{2+}+\mathrm{Mg}^{2+}\right)}$

where the concentration of ions are in $\mathrm{mg} / \mathrm{l}$.

Kelley's ratios for all the groundwater samples are calculated and it lies between 0.6 and $4.4 \mathrm{mg} / \mathrm{l}$. Kelley's ratio value less than one is suitable for irrigation and more than one is unsuitable. According to this classification, only one-third of the total samples are suitable for irrigation.

\section{Corrosivity ratio}

The susceptibility of groundwater to corrosion is denoted by corrosivity ratio (CR), which is expressed as the ratio of alkaline earth metals to saline salts in groundwater (Ryner 1944; Raman 1985). Corrosivity ratio is calculated from the formula,

$\mathrm{CR}=\frac{\left(\frac{\mathrm{Cl}^{-}}{35.5}\right)+2\left(\frac{\mathrm{SO}_{4}^{2-}}{96}\right)}{2\left[\left(\mathrm{CO}_{3}^{2-}+\mathrm{HCO}_{3}^{-}\right) / 100\right]}$

where the concentrations of ions is in $\mathrm{mg} / \mathrm{l}$.
Losses in hydraulic capacity of pipes are an effect of corrosion. About $81 \%$ of samples have the corrosivity ratio greater than one, which cannot be transported through metal pipes. In such cases, the non-corrosive [polyvinyl Chloride (PVC)] pipes can be a better choice for the water transportations (Aravindan et al. 2004).

Spatial distribution

Representing the concentration of various ions on a map is the simplest way to express the groundwater quality information of a study area. In this present work, we attempt to infer the spatial variations using IDW method of ArcGIS ${ }^{\circledR}$ 9.1. Several maps are drawn for each ion separately. Spatial distribution of TDS shows that the concentration was more in the southern region of the study area comparing to the other areas. In the case of total hardness (TH), higher concentration was recorded in southern and northeast areas. Considering calcium, the distribution is more in south and west of the study area. The magnesium map shows higher concentration in several parts of the study area, but it is high in south and north east also. Spatial distribution map of sulfate demarcates that the southern area is having higher concentration comparing to the other areas, the stations W9 and W16 also showing higher concentration. Sodium ions are also distributed similar to the sulfate ions. The region around wells 15 and 17 in south and east of the study area shows high 


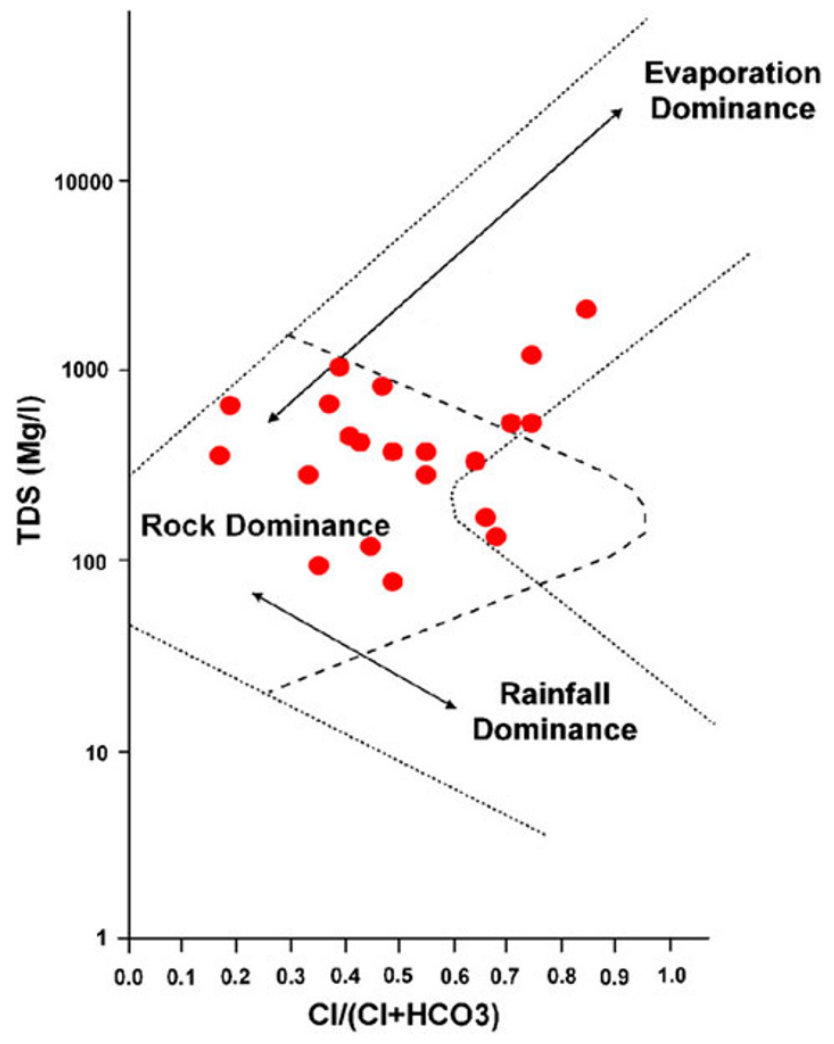

Fig. 14 Gibbs diagram representing the mechanism controlling chemistry of groundwater (Major anions vs. TDS)

concentrations of potassium (K). The bicarbonate distribution is dominant in areas along south, east, and northeast regions. Finally, WQI spatial distribution map shows that the contamination of the groundwater is more in south and eastern part of the study area. From these spatial maps, we can predict that the southern side of the study area has higher concentration for several elements, which seems to be highly polluted. On the southern side of the study area, the groundwater is influenced by saline water intrusion. The irrigation return flow from irrigational activity can also play a leading role in determining the sodium and chlorine content responsible for the salinity. Water hardness arises due to the presence of cations such as calcium and magnesium and anions such as bicarbonates, chlorides and sulfides (Ravikumar et al. 2011).

Gibbs plot

The chemical composition of water and ascertained close relationship that exists between aquifer lithology and water compositional chemistry were proposed by Gibbs (1970) through Gibbs diagram. It has three fields namely precipitation dominance, evaporation dominance, and rock water dominance. Gibb's diagrams were constructed by plotting ratios of

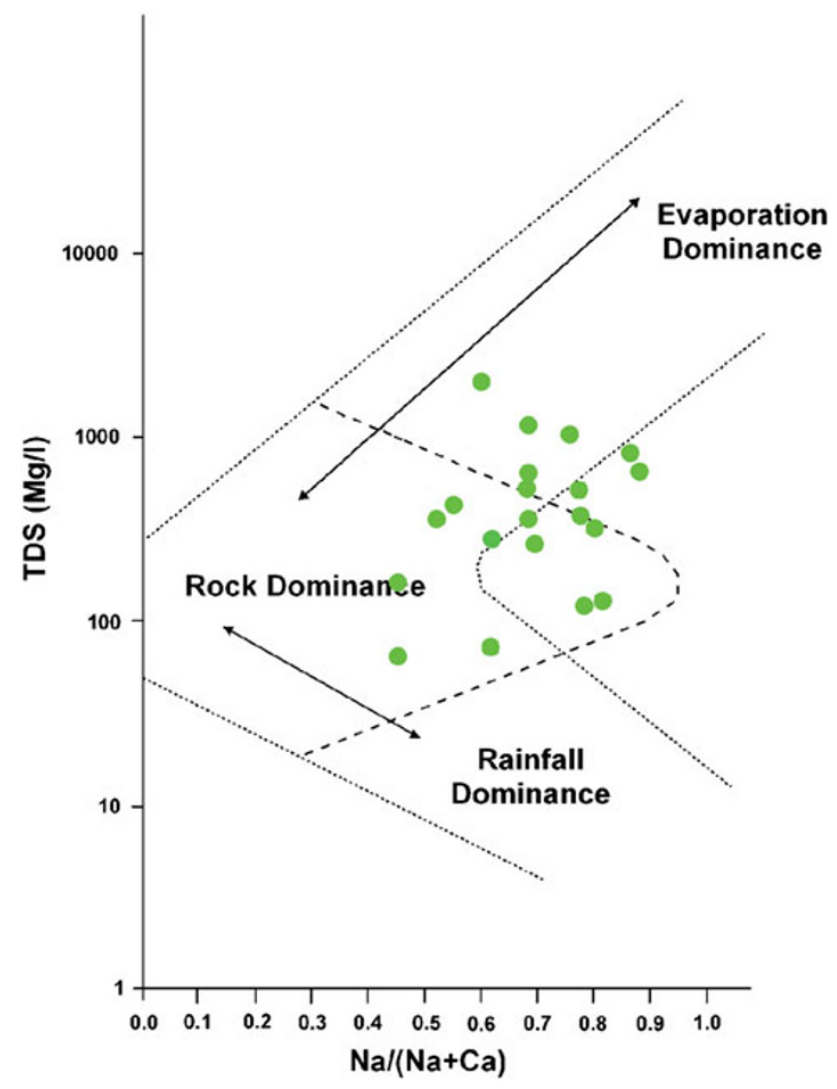

Fig. 15 Gibbs diagram representing the mechanism controlling chemistry of groundwater (Major cations vs. TDS)

(1) dominant anions $\left(\mathrm{Cl}^{-} / \mathrm{Cl}^{-}+\mathrm{HCO}_{3}{ }^{-}\right)$and TDS (Fig. 14) and (2) dominant cations $\left[\left(\mathrm{Na}^{+}+\mathrm{K}^{+}\right)\left(\mathrm{Na}^{+}+\mathrm{K}^{+}+\mathrm{Ca}^{2+}\right)\right]$ and TDS (Fig. 15). The distribution of samples on the Gibbs plots show that majority of them falls in the rock dominant region and the surrounding rock materials plays a key role in concentration of major cations and anions. This suggests that the groundwater seems mostly to be controlled by chemical weathering of rock forming minerals. Some of the samples falling in the evaporation dominance zone show the process of evaporation in the groundwater, which increases with increase in water level as it is in close proximity to the surface (Todd 1980). This may increases the ion concentration in the groundwater. Sometimes it may be due to several other anthropogenic activities.

\section{Conclusion}

The rural to urban migration in Nagercoil town increases urban expansion which in turns leads to several groundwater quality problems. The groundwater geochemistry reveals that the present status of groundwater samples collected in the study area is better for drinking and irrigation purposes 
except few samples, which are crossing the allowable limits of World Health Organization (WHO) standards. The water type $\mathrm{Na}-\mathrm{Mg}-\mathrm{Ca}-\mathrm{Cl}-\mathrm{HCO}_{3}$ is dominating in the study area. Sodium is the most dominant ion, but the common trend was sodium and calcium is the dominant cations with chlorine and bicarbonate as the dominant anions. Even though the majority of samples are within the permissible limits, few are crossing it and some are very close to the allowable limits which indicate there may be a deterioration of water quality in near future. This was because of the interaction of the ground water with sewage and intensive agricultural practices. Based on the WQI classification, only $38 \%$ of samples are perfectly suitable for drinking purpose. Considering the gross salinity, total hardness, $\mathrm{pH}$, and other irrigation parameters, majority of the groundwater samples shows a fresh to highly saline, hard to very hard, slightly alkaline, and excellent to permissible nature, respectively. The calculated chemical parameters such as $\mathrm{Na} \%, \mathrm{SAR}, \mathrm{RSC}, \mathrm{PI}, \mathrm{CR}$, and $\mathrm{KR}$ indicate that the water in the study area can be used for irrigation with improved drainage facilities. High values of electrical conductivity and high concentration of the chemical constituents such as $\mathrm{Na}^{+}, \mathrm{Cl}^{-}, \mathrm{SO}_{4}{ }^{2-}$, and $\mathrm{HCO}_{3}{ }^{-}$ present in the groundwater may be due to dissolution of mineral phases and may be under the influence of anthropogenic activities such as interaction with sewage from urban and industrial waste, massive usage of fertilizers, and intense agricultural practices. From the GIS analyzed spatial maps, we can see that the lower region of the study area has highly affected groundwater quality when compared with the other areas. Gibb's plots confirm that the water chemistry in the area was mostly controlled by weathering of rocks with a minor contribution from atmospheric sources.

The present study estimates the drinking WQI and gives the spatial distribution maps for the chemical constituents in the Nagercoil town and its surroundings. Modern tools such as GIS are used to obtain good and accurate assessment of the quality. The spatial maps derived are helpful for the public to gather knowledge about groundwater pollution. The groundwater samples in few places limit their usage for irrigation. Such areas need adequate drainage and salt tolerance cropping to overcome the problem. The rainwater harvesting structures such as percolation ponds, check dams, recharge pits, and farm ponds can be constructed for the sustainability of quality of groundwater resources.

Acknowledgments The authors sincerely thank the Central Ground Water Board, Chennai for providing necessary literatures relevant to the work. The authors acknowledge the anonymous reviewers for their help to improve the manuscript in the present form.

Open Access This article is distributed under the terms of the Creative Commons Attribution License which permits any use, distribution, and reproduction in any medium, provided the original author(s) and the source are credited.

\section{References}

Adhikary PP, Dash ChJ, Chandrasekharan H, Rajput TBS, Dubey SK (2012) Evaluation of groundwater quality for irrigation and drinking using GIS and geostatistics in a peri-urban area of Delhi, India. Arabian J Geosci 5(6):1423-1434

Agarwal V, Jagetai M (1997) Hydrochemical assessment of groundwater quality in Udaipur city, Rajasthan, India. In: proceedings of national conference on dimensions of environmental stress in India. Department of geology, MS University, Baroda, India, pp 151-154

Ahn H-I, Chon H-T (1999) Assessment of groundwater contamination using geographic information systems. Environ Geochem Health 21:273-289

APHA (1989) Standard methods for the examination of water and waste water, 19th edn. American public health association, Washington, DC

Aravindan S, Manivel M, Chandra Sekar SVN (2004) Groundwater quality in the Hard rock area of the Gadilam river basin, Tamil Nadu. J Geol Soc India 63:625-635

Asadi SS, Vuppala P, Reddy MA (2007) Remote sensing and GIS techniques for evaluation of groundwater quality in municipal corporation of Hyderabad (Zone-V), India. Int J Environ Res Public Health 4(1):45-52

Belkhiri L, Mouni L (2012) Hydrochemical analysis and evaluation of groundwater quality in El Eulma area, Algeria. Appl Water Sci 2:127-133

Bhagavathi Perumal S, Thamarai P (2008a) Groundwater quality after Tsunami in coastal area of Kanyakumari, South Tamilnadu, India. Int J Appl Environ Sci 3-1:37-55

Bhagavathi Perumal S, Thamarai P (2008b) Groundwater level before and after Tsunami in coastal area of Kanyakumari, South Tamilnadu, India. Int J Appl Environ Sci 3(2):139-147 (ISSN 0973)

Bhatia HS (1998) A textbook on environmental pollution and control. Galgotia Publications Pvt. Ltd., India

Brown E, Skougsted MW, Fishman MJ (1974) Methods for collection and analysis of water sample for dissolved minerals and gases. US Department of Interior, book no. 5

Burrough PA, McDonnel RA (1998) Principles of geographical information systems for land resources assessment. Oxford University Press, New York

Burrough PA, McDonnell RA (1998) Principles of geographical information systems. Oxford University Press, Oxford, p 333

Cartwright I, Weaver TR, Fulton S, Nichol C, Reid M, Cheng X (2004) Hydrogeochemical and isotopic constraints on the origins of dryland salinity, Murray Basin, Victoria, Australia. Appl Geochem 19:1233-1254

CGWB (2008) Technical report, Central Ground Water Board

Collins R, Jenkins A (1996) The impact of agricultural land use on stream chemistry in the middle Hills of the Himalayans, Nepal. J Hydrol 185:71-86

Dar IA, Sankar K, Dar MA (2011) Spatial assessment of groundwater quality in Mamundiyar basin, Tamil Nadu, India. J Environ Monit Assess 178:437-447

Debels P, Figueros R, Urrutia R, Barra R, Niell X (2005) Evaluation of water quality in the Chillan river (central Chile) using physicochemical parameters and a modified water quality index. Environ Monit Assess 110:301-322

Durvey VS, Sharma LL, Sainim VP, Sharma BK (1991) Handbook on the methodology of water quality assessment Rajasthan. Agriculture University, India

Eaton FM (1950) Significance of carbonate in irrigation waters. Soil Sci 69:123-133

Freeze RA, Cherri JA (1979) Groundwater. Prentice Hall, Englewood Cliffs 
Garrels A (1976) Survey of low temperature water mineral relations. In: Interpretation of environmental isotope and hydro geochemical data in groundwater hydrology, International Atomic Energy Agency, Vienna, pp 65-84

Gibbs RJ (1970) Mechanics controlling world of water chemistry. Science 17:1088-1090

Goodchild MF (1993) The state of GIS for environmental problemsolving. In: Goodchild MF, Parks BO, Steyart LT (eds) Environmental modeling with GIS. Oxford University Press, New York, pp 8-15

Jain PK (1996) Hydrochemistry and groundwater quality of Singhari river Basin district, Chattapur (M.P.). Pollut Res 15(4):407-409

Jameel AA, Hussain AZ (2011) Monitoring the quality of groundwater on the bank of Uyyakondan channel of river Cauvery at Tiruchirappalli, Tamil Nadu-India. Environ Monit Assess 183(1-4):103-111

Karnath KR (1987) Groundwater assessment, development and management. Tata McGraw Hill, New Delhi

Kaushik AK, Sharma HR, Bhupindar M (2000) Groundwater quality of Ambala and Nilokheri cities in Haryana in relation to landuse. Environ Ecol 18(3):616-623

Kelley WP (1940) Permissible composition and concentration of irrigation waters. In: proceedings of the ASCE 66, pp 607

Korfali SI, Jurdi M (2007) Assessment of domestic water quality: case study, Beirut, Lebanon. J Environ Monit Assess 135:241-251

Krishna Kumar S, Rammohan V, Dajkumar Sahayam J, Jeevanandam M (2011) Assessment of groundwater quality and hydro geochemistry of Manimuktha river basin, Tamil Nadu. J Environ Monit Assess, India

Lo CP, Yeung AKW (2003) Concepts and techniques of geographic information systems. Prentice-Hall of India Pvt. Ltd, New Delhi, p 492

Maiti TC (1982) The dangerous acid rain. Sci Report 9:360-363

Mandel S, Shiftan Z (1981) Ground Water Resources Academic, New York, pp 269

Mathes ES, Rasmussen TC (2006) Combining multivariate statistical analysis with geographic information systems mapping: a tool for delineating groundwater contamination. Hydrogeol J 14:1493-1507

Nas B, Berktay A (2010) Groundwater quality mapping in urban groundwater using GIS. Environ Monit Assess 160:215-227

PWD (2005) Groundwater perspectives: a profile of Kanyakumari district, Tamil Nadu. Tamil Nadu Public Works Department, India

Rajmohan N, Elango L (2005) Nutrient chemistry of groundwater in an intensively irrigated region of Southern India. Environ Geol 47:820-830

Raju NJ, Shukla UK, Ram P (2011) Hydrogeochemistry for the assessment of groundwater quality in Varanasi: a fast-urbanizing center in Uttar Pradesh, India. Environ Monit Assess 173:279-300

Ramakrishna (1998) Groundwater, Handbook, India

Raman V (1985) Impact of corrosion in the conveyance and distribution of water. J Indian Water Works Assn 11:115-121

Ramesh K, Elango L (2012) Groundwater quality and its suitability for domestic and agricultural use in Tondiar river basin, Tamil Nadu, India. Environ Monit Assess 184(6):3887-3899

Ramesh R, ShivKumar K, Eswaramoorthi S, Purvaja GR (1995) Migration and contamination of major and trace elements in ground water of Madras city, India. Environ Geol 25:126-136

Ravikumar P, Somashekar RK, Angami M (2011) Hydrochemistry and evaluation of groundwater suitability for irrigation and drinking purposes in the Markandeya river basin, Belgaum District, Karnataka State, India. J Environ Monit Assess 173:459-487
Regunath HM (1987) Groundwater. Wiley Eastern Ltd, New Delhi, p 563

Revelle R (1941) Criteria for recognition of sea water in groundwaters. Trans Amer Geophys Union 22:593-597

Richards LA (1954) Diagnosis and improvement of saline and alkali soils. Handbook No 60, US Department of Agriculture, Washington, D.C

Rouabhia A, Baali F, Fehdi C, Abderrahmane B, Djamel B (2011) Hydrogeochemistry of groundwaters in a semi-arid region. El Ma El Abiod Aquifer, East Algeria, Arabian J Geosci 4(5-6):973-982

Ryner JW (1944) A new index for determining amount of calcium carbonate scale formed by water. J Amer Wat Assn 36:472-486

Sajil Kumar PJ, James EJ (2013) Physicochemical parameters and their sources in groundwater in the Thirupathur region, Tamil Nadu, South India. Appl Water Sci 3:219-228

Saleh A, Al-Rowaih F, Shehata M (1999) Hydrogeochemical processes operating within the main aquifers of Kuwait. J Arid Environ 42:195-209

Sarath Prasanth SV, Magesh NS, Jitheshlal KV, Chandrasekar N, Gangadhar K (2012) Evaluation of groundwater quality and its suitability for drinking and agricultural use in the coastal stretch of Alappuzha District, Kerala, India. Appl Water Sci 2:165-175

Sawyer CN, Mccarty PL, Parkin GF (2003) Chemistry for environmental engineering and science, 5th edn. McGraw-Hill, New York, p 752

Schoeller H (1977) Geochemistry of groundwater. In: Groundwater studies-an international guide for research and practice, Supplement No. 3 to Groundwater Studies. UNESCO Tech. Papers Hydrol. 7. UNESCO, Paris

Siddiqui A, Naseem S, Jalil T (2005) Groundwater quality assessment in and around Kalu Khuhar, super highway, Sindh, Pakistan. J Appl Sci 5(7):1260-1265

Sreedevi PD (2002) A case study on changes in quality of groundwater with seasonal fluctuations of Pageru river basin, Cuddapah District, Andhra Pradesh, India. J Environ Geol 42:414-423

Srinivasamoorthy K, Nandha Kumar C, Vijayaraghavan K, Vasanthavigar M, Rajiv Gandhi R, Chidambaram S, Anandhan P, Manivannan R, Vasudevan S (2011) Groundwater quality assessment from a hard rock terrain, Salem district of Tamilnadu, India. Arab J Geo Sci 4:91-102

Stafford DB (1991) Civil engineering application of remote sensing and geographic information system. ASCE, New York

Subramani T, Elango L, Damodarasamy R (2005) Groundwater quality and its suitability for drinking and agricultural use in Chittar river basin, Tamil Nadu, India. Environ Geol 47:1099-1110

Swarna Latha P, Nageswara Rao K (2012) An integrated approach to assess the quality of groundwater in a coastal aquifer of Andhra Pradesh, India. J Environ Earth Sci 66:2143-2169

Thomson Jacob C, Azariah J, Viji Roy AG (1999) Impact of textile industries on river Noyyal and riverine groundwater quality of Tirupur, India. Pollut Res 18(4):359-368

Tiwari TN, Mishra M (1985) A preliminary assignment of water quality index of major Indian rivers. Indian $\mathrm{J}$ Environ Prot 5:276-279

Todd DK (1980) Groundwater hydrology, 2nd edn. Wiley, New York USGS (2000) Classification of natural ponds and lakes. US Department of the Interior, US Geological Survey, Washington DC

Vasanthavigar M, Srinivasamoorthy K et al (2010) Application of water quality index for groundwater quality assessment: Thirumanimuttar sub-basin, Tamilnadu, India. J Environ Monit Assess 171:595-609

WHO (1997) Guideline for drinking water quality. Recommendations (Vol. 1, 2nd Edn). Geneva: WHO 
Wilcox LV (1948) The quality for irrigation use. US Department of Agricultural Bulletin 1962, p 40

Wilcox LV (1955) Classification and use of irrigation waters. USDA, Circular 969, Washington, DC
Yidana SM, Yidana A (2010) Assessing water quality using water quality index and multivariate analysis. J Environ Earth Sci 59:1461-1473 